\title{
Isolation and characterization of a novel trophoblast-specific cDNA in the mouse
}

\author{
Kathryn R. Lescisin, Susannah Varmuza, and Janet Rossant \\ Mount Sinai Hospital Research Institute, Toronto, Ontario M5G 1X5 Canada; Department of Medical Genetics, University \\ of Toronto, Toronto, Ontario Canada
}

\begin{abstract}
A novel trophoblast-specific cDNA has been isolated by differential screening of a 13.5-day mouse placental cDNA library. The 755-bp cDNA, which is almost full length, encodes a polypeptide of 124 amino acids with an 18-amino-acid hydrophobic leader sequence. No significant homology with any known gene or protein has been detected. Northern blot analysis has shown that the gene is expressed abundantly in the placenta and is not detected in any other tissues. In situ hybridization revealed that the gene is expressed first in a subgroup of ectoplacental cone cells at 7.5 days of development and its later expression is confined to the spongiotrophoblast cells of the mature placenta. The role of the gene is not currently known, but the presence of a signal peptide suggests that it may be a secreted protein.
\end{abstract}

[Key Words: Trophoblast; placenta-specific DNA; in situ hybridization; mouse]

Received June 2, 1988; revised version accepted October 5, 1988.

The trophoblast cell lineage of the developing mammalian embryo (Fig. 1) produces tissues that are vital to the survival of the fetus. These tissues provide maintenance, nourishment, and protection of the fetus during development. The trophoblast is the first lineage to differentiate in the mammalian embryo, and is one of the most wellcharacterized cell lineages of mammalian development (Rossant 1986). It arises from the trophectoderm of the blastocyst (Fig. 1, 4.5 days) and contributes predominantly to the fetal portion of the mature chorioallantoic placenta in later development.

In an effort to understand the genetic control of development and differentiation of the trophoblast lineage in the mouse, we have sought to identify genes whose expression is specific to this lineage. The results of such a search will provide useful molecular markers for experimental identification of cells of trophoblast origin, where few such markers are available in the mouse (Adamson 1986). In addition, further study should elucidate cis- and trans-acting elements required for gene regulation in the trophoblast lineage. Finally, characterization of trophoblast-specific gene products should aid in understanding the mechanisms by which this tissue carries out its functions.

We report here the isolation of a novel trophoblastspecific cDNA clone by differential screening of a $\lambda \mathrm{gt} 10$ cDNA library made using mRNA derived from 13.5-day mouse placentae. The nucleotide sequence of the clone and the deduced amino acid sequence of the polypeptide are presented. In situ hybridization reveals that expression of the gene is trophoblast-specific and delineates a subgroup of trophoblast cells present in the mouse embryo from 7.5 days until birth.

\section{Results}

\section{Isolation of a placental-specific cDNA clone}

A cDNA library was constructed in $\lambda$ gt 10 using poly $(\mathrm{A})^{+}$ RNA isolated from CD-1 mouse placentae at 13.5 days of pregnancy. Following amplification, $10^{5}$ recombinants were screened differentially using ${ }^{32} \mathrm{P}$-labeled cDNA derived from 13.5-day placenta and ${ }^{32} \mathrm{P}$-labeled cDNA from 13.5-day embryo. Ten plaques which gave strong signals with the placental cDNA probe and not with the embryo cDNA probe were picked. Seven continued to hybridize solely to the placental probe when taken through two rounds of low-density screening. Of these seven cDNA clones, six were shown to cross-hybridize with each other. The seventh clone proved to be mouse placental lactogen II, as determined by hybridization to the mouse placental lactogen II cDNA clone (Jackson et al. 1986). The largest of the six still unidentified clones, clone 4311 , was chosen for further characterization.

\section{Placental specificity of cDNA clone 4311}

Northern blot analysis was performed to confirm the placental specificity of the 4311 clone (Fig. 2). The clone hybridized to a single abundant mRNA species of $\sim 750$ nucleotides in the placenta, but no mRNA was detected in the yolk sac or in the tissues of the embryo proper. The mRNA was first detectable at 10.5 days of gestation, and persisted through all stages examined. No detectable mRNA was seen in $10 \mu \mathrm{g}$ of total RNA from adult kidney, salivary glands, heart, liver, testes, brain, spleen, lymph nodes, and lung tissues (data not shown), even after 2-week exposure periods. Equal amounts of RNA 

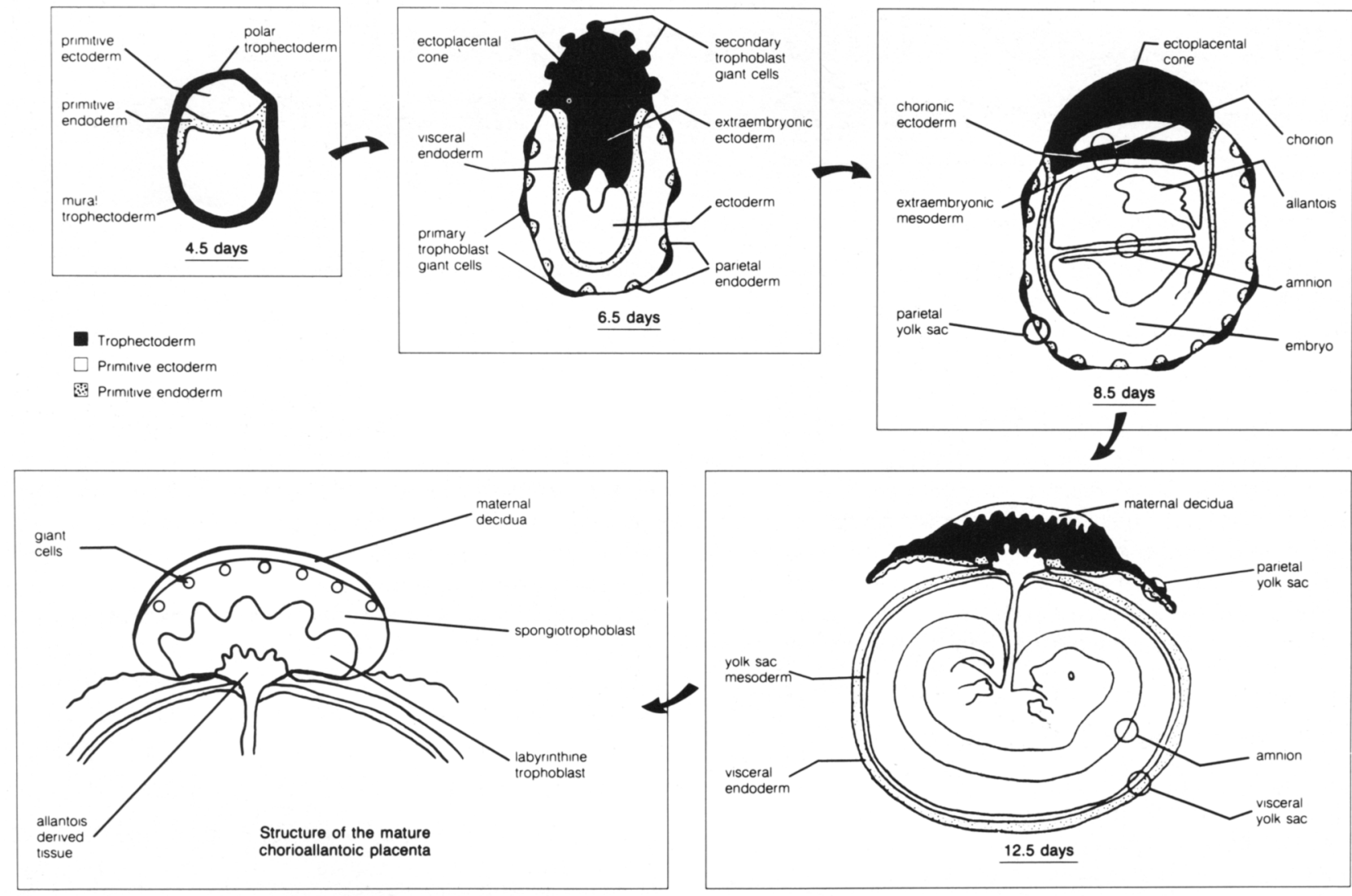

Figure 1. Schematic representation of the trophectoderm, primitive ectoderm, and primitive endoderm lineages during mouse embryonic development.

were loaded in each lane as assessed by signal intensity after hybridization of the blot with a $\beta$-actin probe (data not shown).

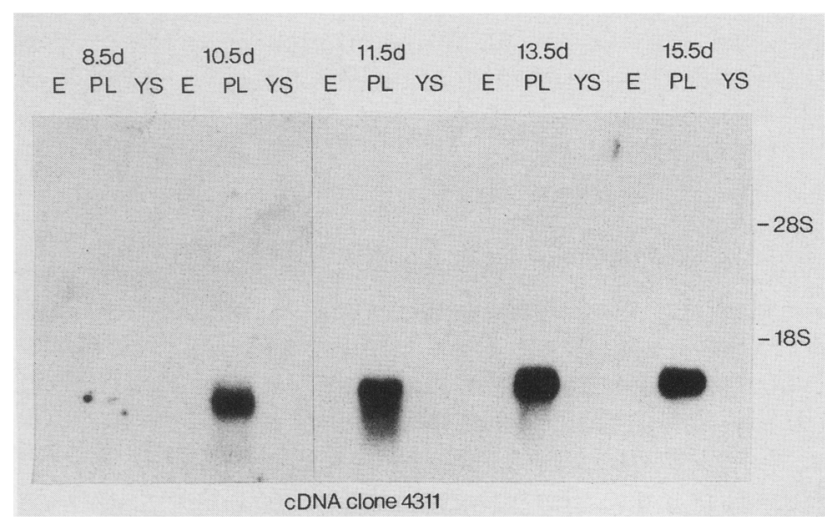

Figure 2. Placental specificity of $4311 \mathrm{mRNA}$. Total RNA was isolated from the embryo (lane $E$ ), placenta (lane $P L$ ) and visceral yolk sac (lane YS) from the embryos at various days of gestation as described in Materials and methods. Hybridization was first detected at 10.5 days of development exclusively in the placenta.

\section{Sequence of mouse cDNA and genomic structure}

Various restriction fragments of clone 4311 were subcloned into pUC118, (Vieira and Messing 1987), and single-stranded sequence analysis was performed according to the strategy outlined in Figure 3 . The $755 \mathrm{bp}$ for clone 4311 and its predicted amino acid sequence are shown in Figure 4.

Primer extension, using a single-stranded primer complementary to nucleotides $41-60$ of clone 4311 , indicated that this clone is missing 5-10 nucleotides from the $5^{\prime}$ end of the mRNA, and is therefore nearly full length (data not shown). There is only one extensive open reading frame, from nucleotides 76 to 450 , predicting a polypeptide of 124 amino acids. The ATG codon at position $76-78$ is used most likely for initiation of translation since it is preceded by stop codons in the reading frame. In addition, this ATG has the most favorable context for initiation according to the analysis of Kozak (1987). The open reading frame ends with the translation termination codon TAA, followed by $257 \mathrm{bp}$ of $3^{\prime}$-untranslated sequence and a poly $(\mathrm{A})$ tract. A poly(A) addition site (Proudfoot and Brownlee 1974) is located $22 \mathrm{bp}$ upstream of the poly(A) tract. Hydrophobicity analysis of the amino acid sequence revealed a hydrophobic region of 21 amino acids at the amino-terminal end of the protein, suggesting the presence of a 


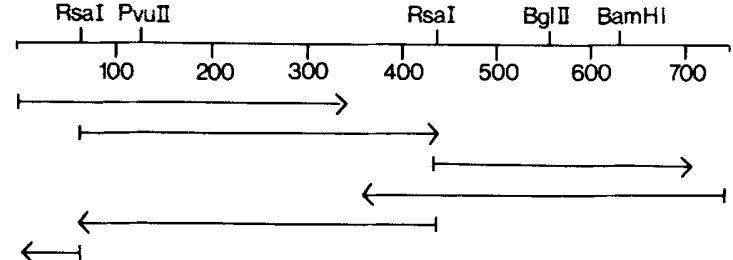

Figure 3. Restriction map and sequencing strategy of cDNA clone 4311 . The restriction sites used in sequencing clone 4311 are diagramed above the linear representation of the clone and the number of base pairs of the cDNA clone are marked below. The arrows indicate the direction of sequencing of the various restriction fragments.

signal peptide (von Heijne 1985). The putative site of cleavage was determined to follow the 18th amino acid according to the rules of von Heijne (1986). No transmembrane domain was found. Nucleotide and protein sequence homology searches (GenBank and NBRF, Genetics Computer Group/ failed to find any significant homologies to previously characterized genes or proteins.

Southern blot analysis of mouse genomic DNA using 4311 as a probe indicated that there is probably only one gene encoding 4311 (Fig. 5). Digestion with enzymes $B a m H I$ and HinfI, which have restriction sites within the known cDNA sequence, generated only two major bands in the Southern blot, as expected for a single-copy gene. Other enzymes such as EcoRI, HindIII, and PstI, which do not cut in the cDNA sequence, also generated MET Thr Pro Thr Ile phe Leu Val Ile Leu Cys Leu Gly Val Ala Ser

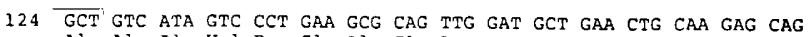
Ala Ala Ile val Pro Glu Ala Gln Leu Asp Ala Glu Leu Gln Glu Gin

172 AaG GAT AAA GAA GTT CTC ATA AaA GCA GTG TGG AGT AAG TTT ATG AAG Lys Asp Lys Glu val Leu Ile Lys Ala val trp Ser Lys phe Met Lys

220 ACT AAC AAA CTM CAC AGT AGC GAA AAT GAC CAG GAG ACG GAA GGC TCC The Asn Lys Leu His Ser Ser Giu Asn Asp Gln Giu thr Glu Gly Ser

268 AAC ATA GAA ATG AGT GCC TCC GGT CAG CTA ACT GAT GAA GAA CTC ATG Asn Ile Glu Met Ser Ala Ser gly gln leu thr asp Giu Glu Leu Met

316 AAA ATA ATG ACT ACT GTT TTA CAC CCA ATG TTT GAA GAG GAG GAA AAC Lys Ile Met thr thr val leu his pro met phe Glu Giu Glu Glu asn

364 AAA CCA CAG CCA GTM GTT GAT GAC CCT GAA TTT GAG GAT TAC ACA GAG Lys pro Gin pro val val Asp asp pro glu phe Glu Asp Tyr Thr Glu

412 AGT GGC GAT GGG TTT TTT GTA CCA AAT CAG CCA CAG TAA CATGGACAGCA Ser Gly asp Gly phe phe val pro Asn Gin pro Gln *

462 GTATGAaGTTAGGCAACGAGCGAAACAGCCACTGTGCCATTGTCTAAGAAATCTCTGCCCCAA

525 CATATGAACTGCCTGATGGTGAAAAAGAGGATCTGAACTGGGGCAAGGGCAAGCAAAACAGC

588 AGGGACTTCCCCAATTCAGTATCCCCTGACAAGTGGGATCCTGCACTCAAGTCCCTTAAATAT

651 ATACTATGATATGAAATCCAAAAGATGTTCACACTAATAAACCTTACCATTACCTTAAAAAA

714 AAAAAAAAAAAAAAAAAAAAAAAAAAAAAAAAAAAAAAA

Figure 4. Nucleotide and predicted amino acid sequences of cDNA clone 4311 . Translation is assumed to begin at the first ATG of the nucleotide sequence (76-78) and continue until the codon TAA $\left({ }^{*}, 448-450\right)$. The polyadenylation signal is underlined and the predicted signal peptide is enclosed between parallel lines.

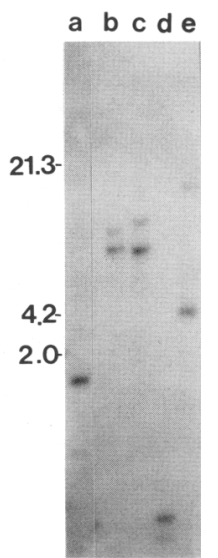

Figure 5. Southern blot of mouse genomic DNA probed with 4311. Lanes: $(a) B a m H I ;(b)$ EcoRI; (c) HindIII, $(d)$ HinfI; (e) PstI.

two bands, suggesting that there is, in fact, an intron in the gene which contains restriction sites for these enzymes. Further resolution of the genomic structure awaits genomic cloning which is underway.

\section{Pattern of expression of 4311 during embryogenesis}

$\left.{ }^{35} \mathrm{~S}\right] \mathrm{UTP}$-labeled probes were transcribed from both the sense and antisense strands of the full $755 \mathrm{bp}$ cDNA clone and were hybridized to $7-\mu \mathrm{m}$ tissue sections of embryos at various stages of embryogenesis. No hybridization was observed with the sense probe at any stage of development. At 6.5 days only a few isolated cells in the ectoplacental cone region hybridized to the antisense probe (data not shown). By 7.5 days, hybridization was detected clearly in a subset of cells at the mesometrial end of the ectoplacental cone region (Fig. 6A,B), as well as in a few isolated cells in the maternal decidua (data not shown). At 8.5-10.5 days of gestation (Fig. 6C-F), mRNA transcripts were detected in a subset of cells in the ectoplacental cone, in a region just below the giant cell layer. In addition, a few isolated cells in the maternal decidua also hybridized to the probe. For stages from 13.5 to 18.5 days of gestation, the placentae were dissected out and hybridized separately from the embryo. No hybridization occurred to any tissues in the developing embryo. The 13.5-, 15.5-, and 18.5-days placentae all contained abundant 4311 transcripts in the spongiotrophoblast region (Fig. 7). The pattern of hybridization was patchy, consisting of dense and sparse areas of silver grains. This patchiness did not seem to reflect any underlying variation in tissue structure. No hybridization occurred to the giant cells nor to the labyrinthine layer, suggesting that 4311 is specific to cells in the spongiotrophoblast, and that it may mark the progenitors of these cells in the earlier stages.

There was also some hybridization to cells in the mesometrial decidual tissue outside the giant cell layer of the placenta, which increased in intensity from 13.5 to 18.5 days of gestation. Whether these cells were maternal or trophoblastic in origin was not clear. Thus, we 

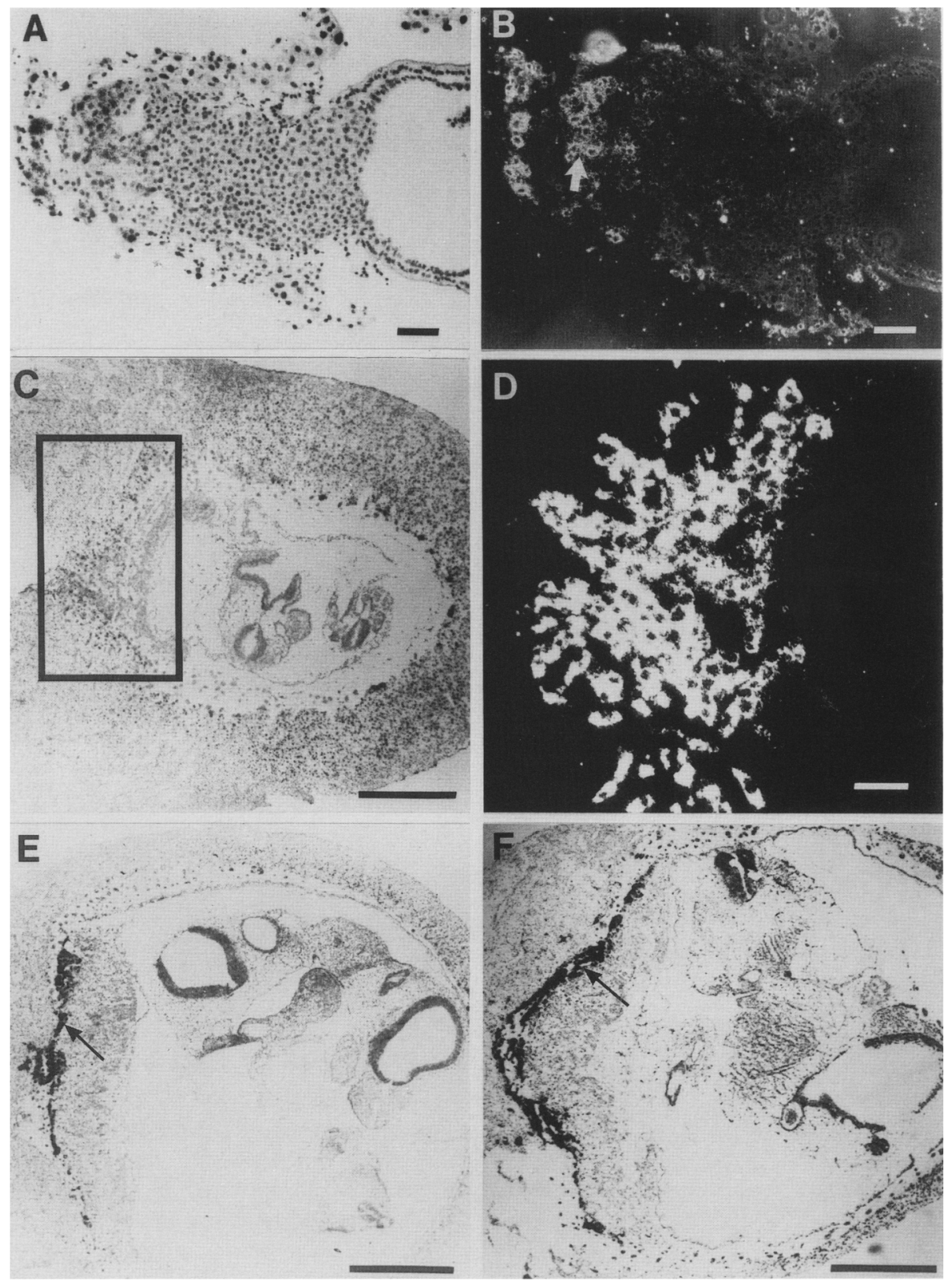

Figure 6. Localization of $4311 \mathrm{mRNA}$ in the mouse embryo by in situ hybridization. $(A, B)$ One-month exposures of 7.5 -day ectoplacental cone photographed under bright-field $(A)$ and dark-field $(B)$ illuminations. The arrow in $B$ denotes a subset of cells in the ectoplacental cone expressing the gene. $(C)$ An 8.5-day embryo in the maternal decidua photographed under bright-field illumination and $(D)$ a higher magnification of the boxed area photographed under dark-field illumination showing the outer ectoplacental cone cells expressing the gene (1-week exposure). $(E, F)$ One-week exposures of 9.5-day $(E)$ and 10.5-day $(F)$ embryos in the maternal decidua showing intense hybridization in the outer regions of the ectoplacental cone (arrows). Grid bar represents $50 \mu \mathrm{m}(A, B, D)$ and $1 \mathrm{~mm}$ $\mid C, E, F)$.

analyzed the genotypic composition of this layer after transfer of genetically marked Tg-M $\beta$ G-1 embryos to CD-1 recipients (Lo 1986; Varmuza et al. 1988). TgMBG-1 is a transgenic line containing $\sim 1000$ tandem copies of a plasmid containing the $\beta$-globin gene. The transgene is detectable by in situ DNA-DNA hybridization, which revealed that there were considerable numbers of $\mathrm{Tg}-\mathrm{M} \beta \mathrm{G}-1$ cells in the maternal layers of the 15.5-day placenta outside of the dense spongiotrophoblast (Fig. 8). These cells must be derived from the trophoblast of the Tg-MBG-1 conceptus, since previous in situ studies have established that no ICM-derived cells are found in this region of the placenta (Rossant and Croy 1985). Thus, it seems likely that 4311 is expressed predominantly in spongiotrophoblast and outlying trophoblast cells in the mature placenta. The presence of 
hybridization in isolated decidual cells earlier in gestation cannot be explained by outlying trophoblast cells, however, since DNA-DNA in situ analysis of Tg-M $\beta \mathrm{G}$ 1 embryos in CD-1 decidua at 8.5 days revealed no labeled cells in this region (data not shown).

\section{Discussion}

A cDNA clone representing a novel placental-specific mRNA has been isolated by differential screening of a 13.5-day mouse placenta cDNA library in $\lambda$ gt10. A single, highly abundant transcript of approximately 750 nucleotides was detected in placental mRNA by Northern blot and primer extension analysis. An almost full-length cDNA clone was sequenced in its entirety and shown to contain a single open reading frame encoding a polypeptide of 124 amino acids with a putative hydrophobic signal sequence of 18 amino acids. No transmembrane domain was found, indicating that the protein is probably processed in the endoplasmic reticulum and secreted from the cell. A search of the nucleotide and protein sequence databases /GenBank and NBRF) revealed no significant homologies to any listed gene or protein. This suggests that the cDNA clone represents a novel gene. Southern blot analysis of genomic DNA indicated that there was probably only one gene encoding 4311.

The tissue-specificity of expression of clone 4311 is regulated tightly in development. Using Northern blot analysis, we were unable to detect transcripts in any tissue analyzed other than the placenta. In situ hybridization revealed that expression was restricted further to a subgroup of fetally derived trophoblast cells within the placenta. Expression was first detected at 7.5 days in a subpopulation of trophoblast cells at the mesometrial end of the ectoplacental cone, and as development proceeded, expression of the gene continued to mark a group of cells in this region of the ectoplacental cone. By 13.5 days of gestation, only the spongiotrophoblast cells of the placenta were expressing the gene. No expression was detected in the trophoblast giant cells, the labyrinthine trophoblast, nor in any tissues of the embryo. Expression was observed in some cells outside the trophoblast giant cell layer in the putative maternal region of the placenta. However, this is not inconsistent with trophoblast-specific expression because some cells in this region were shown to be trophoblast in origin by in situ analysis of genetically marked embryos that had been transferred into unmarked foster mothers. This emphasizes the importance of a full knowledge of the derivatives of a cell lineage such as the trophoblast to make a valid assessment of tissue specificity of expression. The only cells other than trophoblasts that showed any evidence of expression of 4311 were a few isolated cells in the decidua between days 7.5 and 10.5 of development. The significance of this low-level expression is not clear.

Expression of 4311 in a subgroup of trophoblast cells as early as 7.5 days of development suggests that there
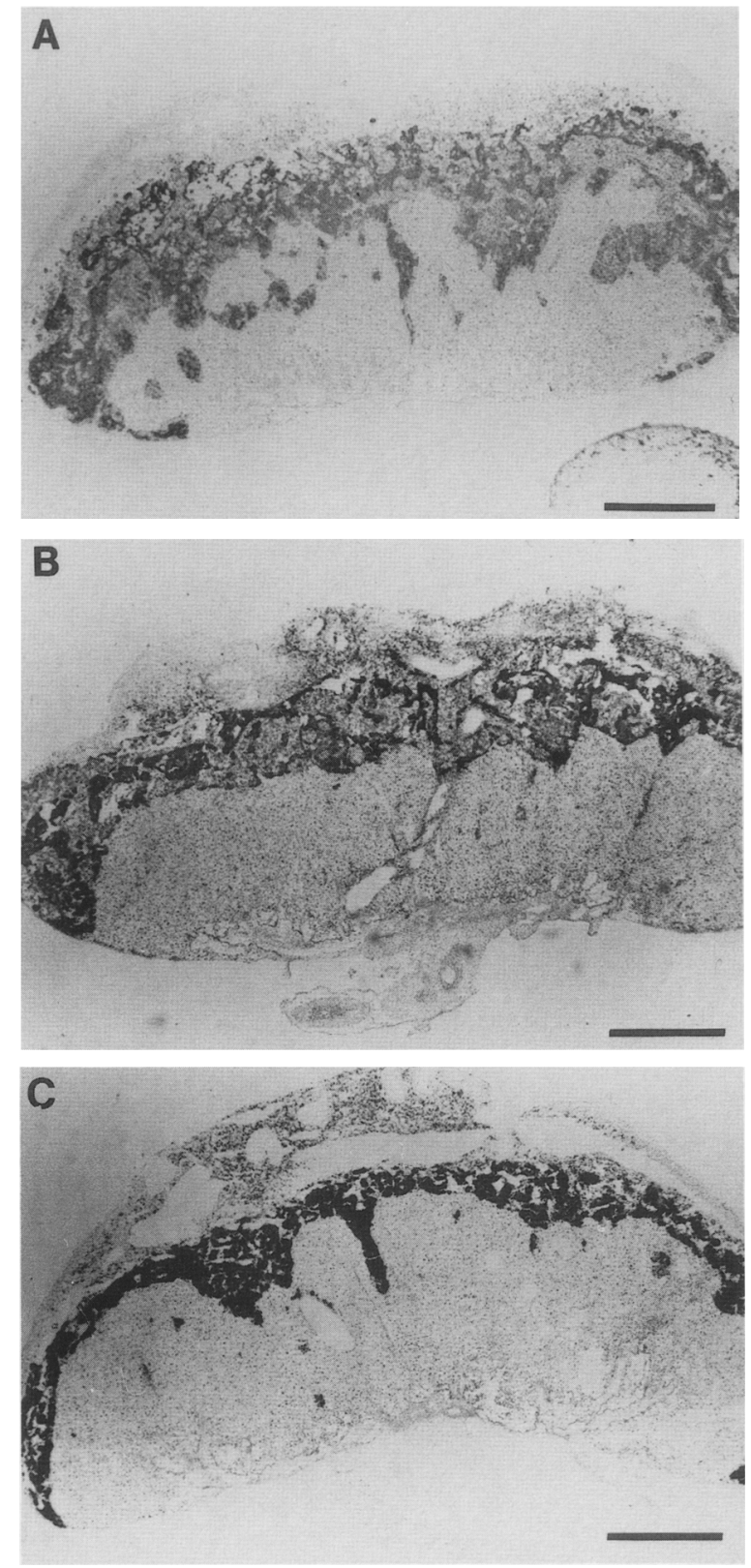

Figure 7. Localization of $4311 \mathrm{mRNA}$ in the mature placenta. Two-day exposures of 13.5-day placenta $(A), 15.5$-day placenta $(B)$, and 18.5-day placenta $(C)$ showing intense hybridization to the spongiotrophoblast and less intense hybridization to cells in the maternal layer. Patchy hybridization can be seen in the spongiotrophoblast of the 13.5-day $(A)$ and 15.5-day $(B)$ placentae. Bar, $1 \mathrm{~mm}$.

may be early compartmentalization within the ectoplacental cone, with 4311 expression marking those cells that will later form the densely packed, hormone-producing spongiotrophoblast. The mechanism by which 4311 expression is regulated within the trophoblast lineage is unknown, but it is interesting to note that it is the ectoplacental cone cells furthest from the embryo that begin expression of 4311 . In another area of tro- 


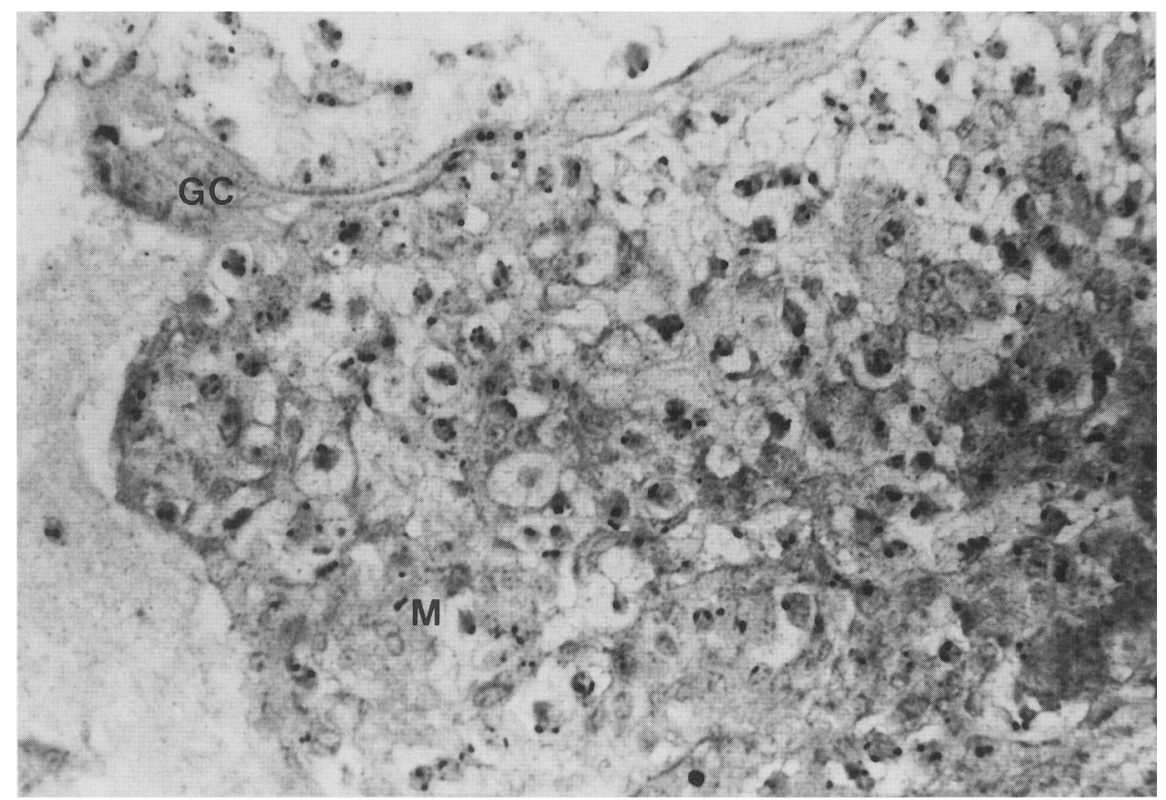

Figure 8. DNA-DNA in situ hybridization of a 15.5-day placenta from the Tg-M $\beta$ G-1 transgenic line transferred into a CD-1 foster mother showing labeled fetal cells in the maternal layer. $(M)$ Maternal decidua; $(G C)$ giant cell layer.

phoblast differentiation, namely trophoblast giant cell formation, it has been shown that the cells of the embryo exert some influence that keeps trophoblast cells in a proliferative state. Only those cells furthest from the influence of the embryo cease division and endoreduplicate (Gardner 1972; Ilgren 1981; Rossant and TamuraLis 1981). It is tempting to speculate that 4311 expression is also affected by the distance of trophoblast cells from embryonic derivatives, thus producing a gradient of trophoblast differentiation with giant cells at the outside, followed by 4311-expressing spongiotrophoblast precursors, and completed by labyrinthine precursors in proximity to the embryonic tissues. This hypothesis would predict that removal of ectoplacental cone cells from the influence of the embryo would extend the domain of expression of 4311 , a concept testable in vitro. Alternatively, the 4311 gene may respond to signals emanating from the maternal uterine tissue. The spongiotrophoblast has been shown to express significant quantities of the colony-stimulating factor (CSF)-1 receptor, c-fms (Regenstreif and Rossant, in prep.), while the overlying maternal epithelium produces large amounts of CSF-1 (Pollard et al. 1987). If 4311 expression is controlled by CSF-1 or some other uterine signal, it may be possible to test this idea by cocultivation of the ectoplacental cone and the pregnant uterus.

A variety of other mouse placental-specific genes have been isolated by screening placental cDNA libraries, including placental lactogens I and II (Jackson et al. 1986, Colosi et al. 1987), proliferin and proliferin-related protein (Linzer and Nathans 1985; Linzer et al. 1985), and placental alkaline phosphatase (Terao and Mintz 1987). However, 4311 is not identical to any of these genes and its isolation by differential screening illustrates that new tissue-specific genes that have not been identified by other approaches can be isolated in this manner. The possible role of 4311 in trophoblast development and differentiation is not yet clear. No similarities with identified proteins, including other secreted proteins (extracellular matrix proteins, proteases, growth factors, peptide hormones, etc.) were revealed by sequence comparisons. Because of its small size, presence of a putative signal peptide, and the abundance of the mRNA, we can speculate that it may be a growth factor/hormone, perhaps involved in interaction between the maternal and fetal systems in maintenance of pregnancy. Currently, we are attempting to raise antibodies to the putative protein to gain more insight into the localization and function of the protein.

Thus, differential screening of a placental cDNA library has allowed isolation of a new trophoblast-specific cDNA whose expression marks a subgroup of trophoblast cells presumably destined to become spongiotrophoblast. This gene is a useful addition to the limited array of mouse trophoblast-specific markers and it may play an important role in the specialized functions of trophoblast in late pregnancy. Early expression could not be detected either by Northern blot analysis or in situ hybridization, suggesting that 4311 may not be required for establishment of the trophoblast lineage, but is instead a marker of terminal differentiation of spongiotrophoblast. A search for genes involved in establishment of the trophectoderm lineage at the blastocyst stage will require sensitive subtractive hybridization of cDNA libraries from earlier stages of development.

\section{Materials and methods}

\section{RNA isolation}

All cellular RNA was prepared as described by Maniatis et al. (1982), with the exception of that used for primer extension. In this case, total cellular RNA was prepared by homogenization 
in $6 \mathrm{M}$ urea $/ 3 \mathrm{M} \mathrm{LiCl}$ with a Polytron homogenizer. After freezing for $18 \mathrm{hr}$ at $-20^{\circ} \mathrm{C}$, the sample was centrifuged at $10,000 \mathrm{rpm}$ for $30 \mathrm{~min}$ at $4^{\circ} \mathrm{C}$. The pellet was resuspended in 7 $M$ urea, $10 \mathrm{~mm}$ Tris- $\mathrm{HCl}$ (pH 8.0), 2 mM EDTA, $200 \mathrm{~mm} \mathrm{NaCl}$, and $1 \%$ SDS; centrifuged at $10,000 \mathrm{rpm}$ for $10 \mathrm{~min}$ at room temperature; extracted twice with phenol/chloroform and twice with chloroform; and ethanol-precipitated with $0.3 \mathrm{M}$ $\mathrm{NaOAc}$ at $-70^{\circ} \mathrm{C}$. Poly $(\mathrm{A})^{+} \mathrm{RNA}$ was isolated from oligo(dT) columns according to Maniatis et al. (1982).

\section{Isolation of placental-specific cDNA clones}

Pregnant CD-1 mice were sacrificed on day 13.5 of gestation (day of plug is day 0.5 ) and six placentae were dissected free of maternal and embryonic tissues, yielding $450 \mu \mathrm{g}$ of total RNA, and $30 \mu \mathrm{g}$ of poly $(\mathrm{A})+$ RNA. cDNA was synthesized from $1 \mu \mathrm{g}$ of poly $(\mathrm{A})^{+} \mathrm{RNA}$ according to the method of Gubler and Hoffman (1983), and cloned into $\lambda$ gt 10 (Hyunh et al. 1985). The library, consisting of $10^{5}$ clones, derived from $45 \mathrm{ng}$ of cDNA, was amplified in $\mathrm{C}_{600} \mathrm{Hfl}^{-}$cells.

The library was screened by differential hybridization (Maniatis et al. 1982) using [ $\left.{ }^{32} \mathrm{P}\right] \mathrm{dCTP}$-labeled CDNA probes that were made from oligo(dT)-primed poly $(\mathrm{A})^{+}$RNA from 13.5-day placentae and 13.5-day embryos. Signals that were positive with the placental probe and negative with the embryo probe were picked, and taken through two rounds of low-density screening. The plaques that continued to test positive only with the placental probe were picked and phage DNA was isolated according to Maniatis et al. (1982).

\section{Northern and Southern blotting}

Total cellular RNA from yolk sac, embryo, and placental tissues at various stages of embryogenesis was electrophoresed in a glyoxal agarose gel according to Maniatis et al. (1982), and transferred to GeneScreen Plus (NEN), as described by the manufacturer. Filters were prehybridized at $42^{\circ} \mathrm{C}$ for $1 \mathrm{hr}$ in $50 \%$ formamide, $1 \%$ SDS, $10 \%$ dextran sulfate, and $1 \mathrm{M} \mathrm{NaCl}$. Hybridization took place in the same buffer at $42^{\circ} \mathrm{C}$ for $18 \mathrm{hr}$ with $100 \mu \mathrm{g} / \mathrm{ml}$ denatured, sheared herring sperm DNA, and ${ }^{32} \mathrm{P}-\mathrm{la}$ beled clone 4311 DNA, prepared by random priming (Feinberg and Vogelstein 1983). The filters were washed at $65^{\circ} \mathrm{C}$ in $2 \times$ SSC and $1 \%$ SDS, followed by a more stringent wash at $0.2 \times$ SSC and $0.1 \%$ SDS at $65^{\circ} \mathrm{C}$.

Total cellular RNA prepared from various mouse adult tissues was electrophoresed on a formaldehyde gel and transferred to GeneScreen Plus (NEN) according to Joyner et al. (1985). The filter was prehybridized at $65^{\circ} \mathrm{C}$ for $30 \mathrm{~min}$ in $15 \%$ formamide, $0.5 \mathrm{M} \mathrm{Na}_{2} \mathrm{HPO}_{4}, 1 \mathrm{mM}$ EDTA, $1 \% \mathrm{BSA}$, and $7 \%$ SDS. Hybridization took place in the same buffer for $16 \mathrm{hr}$ at $65^{\circ} \mathrm{C}$ with random primed clone 4311 DNA (Feinberg and Vogelstein 1983). The filter was washed in $150 \mathrm{mM} \mathrm{Na} \mathrm{HPO}_{4} / 1 \%$ SDS at room temperature and at $50^{\circ} \mathrm{C}$, in $30 \mathrm{mM} \mathrm{Na}{ }_{2} \mathrm{HPO}_{4} /$ $0.1 \%$ SDS at $50^{\circ} \mathrm{C}$, and finally in $15 \mathrm{mM} \mathrm{Na}_{2} \mathrm{HPO}_{4} / 0.1 \% \mathrm{SDS}$ at $65^{\circ} \mathrm{C}$.

Genomic DNA prepared from CD-1 mouse spleens was digested with various restriction enzymes according to the manufacturer's directions. Sample aliquots of $5 \mu \mathrm{g}$ were loaded in an $0.8 \%$ agarose gel and subject to electrophoresis. After transfer to GeneScreen Plus, blots were prehybridized for $4 \mathrm{hr}$ at $65^{\circ} \mathrm{C}$ in $10 \%$ dextran sulfate, $1 \%$ SDS, $1 \mathrm{M} \mathrm{NaCl}$, and $100 \mu \mathrm{g} / \mathrm{ml}$ salmon sperm DNA. Random-primed $4311 \mathrm{cDNA}$ probe was added at $4 \times 10^{6} \mathrm{cpm} / \mathrm{ml}$ and hybridization took place overnight at $65^{\circ} \mathrm{C}$. All washes were at $65^{\circ} \mathrm{C}$ with the final wash containing $0.1 \times$ SSC and $1 \%$ SDS.

\section{Sequencing}

Restriction fragments of cDNA clone 4311 were subcloned into pUC11 8 and single-stranded DNA was prepared as described by Vieira and Messing (1987). Both strands of the subclones were sequenced by the dideoxy chain-termination method using the Sequenase enzyme (U.S. Biochemical Corporation), according to the method described by the manufacturer.

\section{In situ hybridizations}

In situ hybridization was performed using the method as described by Davis et al. (1988). Briefly, embryos and placentae were dissected from the uterus between days 8.5 and 18.5 of development, and 7- $\mu \mathrm{m}$ frozen sections were collected and fixed in 4\% paraformaldehyde as described (Davis et al. 1988). The ${ }^{35}$ S]UTP-labeled single-stranded RNA probes were prepared from pGeml and pGem2 (Promega) plasmids containing the full-length 4311 clone, thus transcribing both strands of the clone. Hybridizations, washes, autoradiography, and staining were performed according to Davis et al. (1988). Coverslips were mounted, and the slides were examined under transmitted light- and dark-field illumination. Some tissues were subject to in situ hybridization after ester wax embedding. Embryos of 6.5 and 7.5 days were dissected from the decidua, and 15.5-day placentae were fixed in $4 \%$ paraformaldehyde for $10 \mathrm{~min}$, dehydrated in an ethanol series at $4^{\circ} \mathrm{C}$, and embedded in ester wax (BDH 1940). Sections of $7 \mu \mathrm{m}$ were collected on poly-L-lysinecoated slides and dried at $37^{\circ} \mathrm{C}$. The slides were treated in $x y-$ lene for $5 \mathrm{~min}$ to dissolve the wax, rehydrated in an ethanol series, acetylated in a freshly prepared solution of $0.25 \%$ acetic anhydride and $100 \mathrm{mM}$ triethanolamine $(\mathrm{pH} 7.5)$, rinsed in $3 \times$ PBS for $5 \mathrm{~min}$ and twice in $1 \times$ PBS for $3 \mathrm{~min}$, dehydrated in ethanol, and air-dried. Probe preparation, hybridizations, washes, and autoradiography were then performed as for cryostat sections (Davis et al. 1988).

\section{In situ identification of embryo-derived cells in the placenta} and decidua

Blastocysts were recovered from matings between mice homozygous for the transgenic marker, Tg-M $\beta$ G-1 (Lo 1986; Varmuza et al. 1988), and transferred to the uteri of pseudopregnant CD-1 recipient females. Recipients were sacrificed at 8.5, 12.5, and 15.5 days of pregnancy and intact decidua containing the transferred embryos were fixed in acetic acid/ethanol $(1: 3)$, and processed for ester wax embedding (Rossant 1985). Sections of $7 \mu \mathrm{m}$ were hybridized in situ with biotinylated $\mathrm{pM} \beta \Delta 2$ DNA, which is homologous with the transgenic insert, and hybridization was detected by streptavidin-horseradish peroxidase binding as described previously (Varmuza et al. 1988). Nuclei containing positive hybridization signals identified cells of fetal origin in the developing placenta or decidua.

\section{Acknowledgments}

We should like to thank Valerie Prideaux for technical assistance. This work was supported by grant HD 22596-02 from the National Institute of Child Health and Human Development. J.R. holds a Senior Scientist award and S.V. a fellowship from the National Cancer Institute of Canada.

\section{References}

Adamson, E.D. 1986. Cell lineage-specific gene expression in development. In Experimental approaches to mammalian 
embryonic development (ed. J. Rossant and R.A. Pedersen), pp. 321-364. Cambridge University Press, New York.

Colosi, P., F. Talamantes, and D.I.H. Linzer. 1987. Molecular cloning and expression of mouse placental lactogen I complementary deoxynucleic acid. Mol. Endocrin. 1: 767-776.

Davis, C.A., S.E. Noble-Topham, J. Rossant, and A.L. Joyner. 1988. Expression of the homeo box-containing gene En-2 delineates a specific region of the developing mouse brain. Genes Dev. 2: 361-371.

Feinberg, A.P. and B. Vogelstein. 1983. A technique for radiolabeling DNA restriction endonuclease fragments to high specific activity. Anal. Biochem. 132: 6-13.

Gardner, R.L. 1972. An investigation of inner cell mass and trophectoderm tissues following their isolation from the mouse blastocyst. J. Embryol. Exp. Morph. 28: 279-312.

Gubler, U. and B.J. Hoffman. 1983. A simple and very efficientmethod for generating cDNA libraries. Gene 25: 263-269.

Hyunh, T.V., R.A. Young, and R.W. Davis. 1985. Constructing and screening cDNA libraries in $\lambda g t 10$ and $\lambda g t 11$. In DNA cloning-a practical approach (ed. D.M. Glover), vol. 1, pp. 49-78. IRL Press, Oxford.

Ilgren, E.B. 1981. On the control of the trophoblastic giant-cell transformation in the mouse: homotypic cellular interactions and polyploidy. J. Embryol. Exp. Morph. 62: 183-202.

Jackson, L.L., P. Colosi, F. Talamantes, and D.I.H. Linzer. 1986. Molecular cloning of mouse placental lactogen II cDNA. Proc. Natl. Acad. Sci. 83: 8496-8500.

Joyner, A.L., T. Kornberg, K.G. Coleman, D.R. Cox, and G.R. Martin. 1985. Expression during embryogenesis of a mouse gene with sequence homology to the Drosophila engrailed gene. Cell 43: 29-37.

Kozak, M. 1987. An analysis of $5^{\prime}$-noncoding sequences from 699 vertebrate messenger RNAs. Nucleic Acids Res. 15: 8125-8148.

Linzer, D.I.H. and D. Nathans. 1985. A new member of the prolactin growth hormone gene family expressed in mouse placenta. EMBO I. 4: 1419-1423.

Linzer, D.I.H., S.J. Lee, L. Ogren, F. Talamantes, and D. Nathans. 1985. Identification of proliferin mRNA and protein in mouse placenta. Proc. Natl. Acad. Sci. 82: 43564359.

Lo, C. 1986. Localization of low abundance DNA sequences intissue sections by in situ hybridization. J. Cell Sci. 81: 143162.

Maniatis, T., E.F. Fritsch, and J. Sambrook. 1982. Molecular cloning: a laboratory manual. Cold Spring Harbor Laboratory, Cold Spring Harbor, New York.

Pollard, J.W., A. Bartocci, R. Arceci, A. Orlofsky, M.B. Ladner and E.R. Stanley. 1987. Apparent role of the macrophage growth factor, CSF-1, in placental development. Nature 330: 484-486.

Proudfoot, N.J. and G.G. Brownlee. 1974. Sequence at the 3' end of globin mRNA shows homology with immunoglobulin light chain mRNA. Nature 252: 359-362.

Rossant, J. 1985. Interspecific cell markers and lineage in mammals. Philos. Trans. R. Soc. Lond. Biol. 312: 91-100.

1986. Development of the extraembryonic cell lineages in the mouse embryo. In Experimental approaches to mammalian embryonic development (ed. J. Rossant and R.A. Pedersen), pp. 97-120. Cambridge University Press, New York.

Rossant, J. and W. Tamura-Lis. 1981. Effect of culture conditions on diploid to giant-cell transformation in postimplantation mouse trophoblast. J. Embryol. Exp. Morph. 62: 217227.

Rossant, J. and B.A. Croy. 1985. Genetic identification of tissue of origin of cellular populations within the mouse placenta. J. Embryol. Exp. Morph. 86: 177-189.

Terao, M. and B. Mintz. 1987. Cloning and characterization of a cDNA coding for mouse placental alkaline phosphatase. Proc. Natl. Acad. Sci. 84: 7051-7055.

Varmuza, S., V. Prideaux, R. Kothary, and J. Rossant. 1988. Polytene chromosomes in mouse trophoblast giant cells. $D e$ velopment 102: 127-134.

Vieira, J. and J. Messing. 1987. Production of single-stranded plasmid DNA. In Methods in enzymology (ed. S.L. Berger and A.R. Kimmel), vol. 153, pp. 3-11. Academic Press, Orlando, Florida.

von Heijne, G. 1985. Signal sequences - the limits of variation. I. Mol. Biol. 184: 99-105.

. 1986. A new method for predicting signal sequence cleavage sites. Nucleic Acids Res. 14: 4683-4690. 


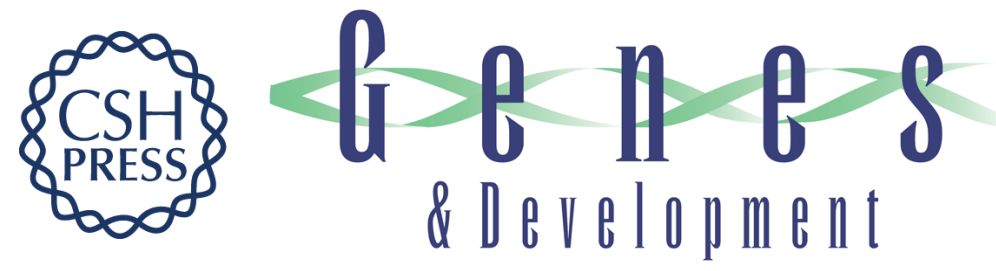

\section{Isolation and characterization of a novel trophoblast-specific cDNA in the mouse.}

K R Lescisin, S Varmuza and J Rossant

Genes Dev. 1988, 2:

Access the most recent version at doi:10.1101/gad.2.12a.1639

References This article cites 21 articles, 6 of which can be accessed free at:

http://genesdev.cshlp.org/content/2/12a/1639.full.html\#ref-list-1

License

Email Alerting

Service

Receive free email alerts when new articles cite this article - sign up in the box at the top right corner of the article or click here.

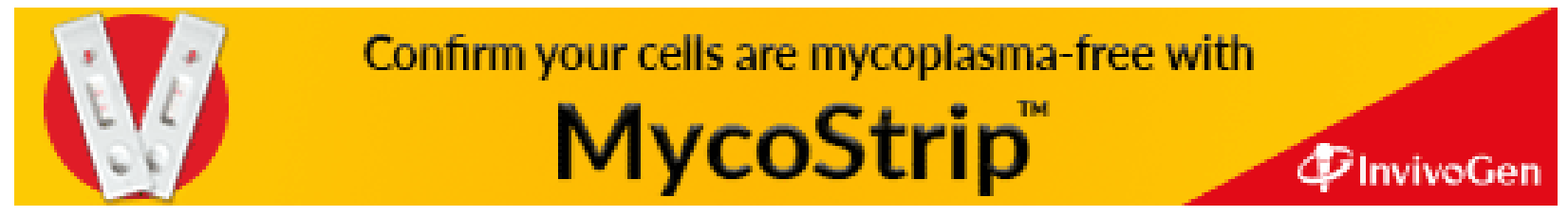

